\title{
THE MOBILITY OF EDUCATION POLICY IN THE 21st CENTURY: LESSONS FROM OTHER FIELDS
}

\author{
Alan Ruby ${ }^{1}$ \\ University of Pennsylvania, USA
}

Aisi Li

Nazarbayev University, Kazakhstan

\begin{abstract}
This paper seeks to connect the work on policy mobility in education and that in other fields through a review of literature. Drawing on material from political science, international relations, geography, and economic and social development, it discusses different forms of policy mobility like traveling policies, policy borrowing, and silent borrowing. It concludes that policy transfer is a more dynamic process than the bounded cyclical and linear models often used in education policy debates.
\end{abstract}

Keywords: policy borrowing, policy mobility, traveling policy, silent borrowing, non-linear transfer

\section{Introduction}

Tighter connections between public policy makers formed during the latest wave of globalization changed the ways information about national education policies was exchanged and interpreted. International travel became cheaper, cross border telephone and video costs shrank, and print and digital coverage of educational policies and practices expanded. Yet the way these exchanges are discussed and analyzed in the field of education policy is underdeveloped and seems to ignore the insights and models prevalent in other domains. This paper seeks to draw together some of that scholarship and identify ideas and concepts that might inform our better understanding of the movement of education policies between nations.

The need for more attention to the mobility of policies is fueled in part by increased public policy attention to education reform starting in the mid 1980's and plateauing around

\footnotetext{
${ }^{1}$ Correspondence: Room 202, Siteler Hall, 208 South 37th Street, Philadelphia, 19104; alanruby@upenn.edu
} 
2002, as illustrated by English language references to education reform in Google Books Ngram viewer for the period 1960-2008. During that period, international agencies created new tools like the OECD's PISA tests of student achievement and The World Bank's SABER data base on educational policies to help decision makers make comparisons between national and provincial school systems education, such as Auld \& Morris (2014) and Silova (2018). Policy makers looked to high performing school systems for practice that could be imported even when the enabling environment is fundamentally different (Oates, 2010).

For example, the outstanding performance of Finland on PISA tests encouraged greater scrutiny of its schools and educational policies. Some saw Finland as a global model of education worthy of emulation by both industrialized democracies and developing economies. The key features were a "priority on learning," good learning outcomes for all students, and embedding assessment in teaching and learning processes (Sahlberg, 2006). A similar "set of policy reforms symbolizing Western education values and including such 'travelling policies' as student centered learning" were sometimes "imposed" and in other cases "voluntarily borrowed" by former socialist republics (Silova, 2010).

A common explanation for the spread of this model was economic competition (Sahlberg, 2006; Steiner-Khamsi, 2014; Nir \& Emil, 2017). It was credited with waves of "traveling policies," policy borrowing, and policy convergence that were embedded in globalization. National education policies became more alike because "problems and challenges are similar" and "solutions and education reforms are also becoming similar" (Sahlberg, 2015).

Our contention is that this is a simplified way to think about the cross-national movement of policy ideas in education. As Oates (2010) points out, drawing lessons from high performing school systems about the content of a national curriculum needs to be done "with sophistication and sensitivity" (p.17), but there is little guidance on how to go about this analysis. What work there is tends to overlook the basic conceptual work in comparative education by scholars like Phillips and Ochs (2003,2004) and more recently by Rappleye (2011), who argued that political actors were "resorting to carefully scripted and executed attempts to use 'references to elsewhere' to drive domestic reforms" (p.140). It also often does not relate to the work on policy mobility in other fields, notably public policy.

This paper seeks to remedy this latter shortcoming through a review of literature in education and other fields. It begins with a brief reprise of some historical examples of policy transfer. It then lays out different forms of policy borrowing drawing on material from a range of fields such as political science, international relations, geography, and economic and social development. This is followed by a discussion of different forms of policy mobility like traveling policies, policy borrowing, and silent borrowing. We conclude with the observation that non-linear transfer, which can include unplanned and unintended adaptation and adoption, often takes place in policy mobility. Policy transfer is a more dynamic process than the bounded cyclical and linear models often used in education policy debates.

\section{Policy Transfer is Not New}

Learning from and borrowing the policies and practices of others is not a new phenomenon. Rose (2004) cites Plato, Aristotle, Thucydides, King George III and Thomas Jefferson as examples of people learning from "abroad." In all cases he argues the goal was to improve practice or to avoid error or failure (p.117). Robertson \& Waltman (1993) also invoke Plato and leap into the $20^{\text {th }}$ century to cite Thatcher and Reagan as political leaders who borrowed policies. Anthropologists have long grappled with the question of how ideas or practices were exchanged between societies and spread from the point of invention to others. 
But much of the early research was focused on the adoption of new practices or technologies like hybrid seed corn and weed spray by individual farmers. It examined the movement of ideas as a "social process" where individual opinion leaders served as models and sources of information for others (Rogers, 2003). It did not address policy transfer between nation states, although it did extend to cover public health practices and information technology using the language of innovators, early adopters, and laggards to describe how different sets of individuals took up new approaches. The emphasis on adoption is characterized as a "demand" approach where individuals look for better products (Brown, 1981).

The contrasting "supply" approach to policy mobility is more concerned with the provider of information rather than the characteristics of the adopter. Both the supply and demand approaches assume that the innovation or policy idea is "essentially the same throughout the diffusion process" (Brown, 1981). Neither acknowledges that there is likely to be some measure of acculturation as an idea crosses a border. They overlook the certainty that "a transmitted cultural trait never retains its whole identity" (Godin, 2014) and ignore insights from economic history about the lags between the invention, improvement, and widespread adoption of new technologies. Some of these lags are shaped by cost and users' skills as well as by wider contextual factors like resource scarcity (Brown, 1981).

Political scientists and international relations scholars have examined the spread of public policies for more than 60 years; with a rapid growth of academic interest in the late 1990's (see Graham et al, 2012). A review of some of that literature (Stone, 2012) suggests that early formulations, focused on policy diffusion in the USA's federal system, invoked osmosis and contagion as images describing the movement of ideas and practices. Transfer is an alternative formulation to describe the movement of public policies. It assumes some degree of rationality in policy formulation with purposeful selection and modification of ideas from other jurisdictions. The model may result in "selective borrowing that leads to hybrids and adaptive innovation to... better fit local conditions" (Stone, 2012). Studies using this framework tend to concentrate on how policies are transferred rather that which ideas are crossing boundaries.

The third formulation that Stone observes in the political science literature is "policy translation," which stresses the importance of context and the interpretation of ideas as they are received. The process is more than the acquisition of some technical knowledge; it involves adaptation and adjustment to align with cultural and economic circumstances. This process of refinement or acculturation will continue after the time of transfer and initial implementation (Stone, 2012).

\section{An Abundance of Metaphors}

How we talk about this process of emulation or how ideas are exchanged or applied is bedeviled by the slipperiness of the English language, the mode of discourse for many actors. Metaphors, similes, and neologisms to describe the products of these relationships abound. Some seem apt, and others do not stand up under closer scrutiny. For example, the "osmosis" analogy refers to the transfer from a concentrated solution to a more dilute solution across a permeable membrane. The process stops when the two solutions are of equal density; one solution losses and the other gains. In the policy world the sharing of ideas does not deplete the stock of the originator.

Some images are tied to particular contexts like the use of the term "loan words" in

South Korea to describe policies that originated in Anglo-Saxon environments (Sung, 2011). Others draw from medicine, referring to transfusions, transplants, and grafts, although seldom mentioning tissue rejection or immune responses to the presence of foreign matter. 
The geographers prefer to talk about policy mobility because that formulation acknowledges the influence of place and culture and the possibility that policies might mutate when they are transferred (Peck \& Theodore, 2010). Portnoi (2016) prefers policy diffusion to describe the spread of similar policies, a convergence of policies and practices like standardized testing and lifelong learning. Critics of the diffusion model argue that diffusion ignores the likelihood that practices and policies will change as they are adopted and implemented and tends to overlook interactions between political actors as an exchange mechanism.

A refinement of the geographic approach is set out by Beech (2009), who argues that thinking about the movement of ideas solely in terms of movement between "places" overlooks flows of ideas within and between networks which are not defined by proximity or controlled by sovereign states. He observes that networks have become more inclusive and open to many voices because of cheaper and more pervasive communications technology. Beech does not look at instances where a policy or practice did not transfer. Sprigade's (2004) essay on educational comparisons in English policy making in the 1800's gives an example of a study of elementary education in other settings, which led to the conclusion that neither of two prevailing models, Scotland and continental Europe, would suit.

In the economic and social development literature there are references to coercive policy transfer where practices are to be adopted as a prerequisite for the grant or release of loan funds (Eta \& Vuban, 2018). It is distinguished from persuasive policy transfer, which is associated with technical assistance, training programs, and advisory services offered by various lending and grant making agencies (Bazbauers, 2017).

Coercive policy borrowing can be either explicit and direct, like formal loan conditions, or indirect. A nation's desire to have its educational credentials recognized by its neighbors or by a former colonial power can lead it to adopt a set of standards. This apparently voluntary act is shaped by a desire to increase job opportunities for its citizens, as in the case of Tunis and its adoption of the main elements of the Bologna Process (Jules \& Bouhlila, 2018). Or it can be influenced by the decisions of supra-national groups like the regular meeting of the heads of states of Central Africa, which led Cameroon to adopt, for at least part of the country, a three- degree structure which was comparable and comprehensible nationally and regionally (Eta \& Vuban, 2018)

Others talk of policy mimesis where a policy or form of words used by one entity is imitated or mimicked by another. Imitation may be a product of competition, where like organizations act in identical ways, replicating the innovations or decisions of others (Strang \& Soule, 1998). The incentive is to be the same as another actor that is sometimes described as isomorphism. Massey (2009), for example, discusses isomorphism in public policy where both "coercive and mimetic isomorphism may be observed," arguing that the phenomena is more than an act of "copy and paste' because it occurs in a different context. Similarly, Varia (2004) uses the concept of isomorphism to discuss the move to homogenous higher education. He sees the persistence and even the rise of heterogeneity of institutions as product of the influence of place and the plurality of decisions made by different nation states. To integrate the two trends, Varia adopts the idea of allomorphs from linguistics, where an allomorph is a variant form of a word where usage is determined by context.

A different approach to isomorphism is offered by Erlingsdottir \& Lindberg (2005), who distinguish two different forms. One is isopraxism where policy or practice transfers unchanged but gets a new name. The other is isonymism where the name is invariant, but the elements of the policy evolve or adapt.

These ideas of coercion, imitation, and congruence are drawn together by Garrett, Dobbin, and Simmons (2008) in a synthesis of seven studies of the spread of free markets and 
democracy. They begin by criticizing the proposition that similar national responses to broad pervasive forces, like easier movement of capital, suggest either policy convergence or isomorphism. They argue that while the convergence model accounts for the importance of common stimuli and allows for variation produced by different domestic characteristics, it does not allow for purposeful action by national decision makers. They prefer to look at the influence of four mechanisms that might diffuse policy ideas across national boundaries: "coercion, competition, learning and emulation" (p.345). They conclude that emulation and competition had more impact on the spread of "political and economic liberalism" than coercion and learning (p.346), although all four do contribute to traveling policies.

\section{Traveling Policies}

Traveling policies is a term used to describe the spread of reform ideas across boundaries. One early reference is Sautoy's 1967 note on the movement of ideas in rural development. He highlighted the difficulties of communication between expert advisors and the audience that often resulted in misunderstanding, particularly when the ideas were expressed in complex language.

Yet the use of "traveling" implies that the policies keep moving and evokes images of tourists looking at landmarks and eating local food and returning home after a short time. Indeed, policy tourism is sometimes used as a pejorative and equated with the collection and retelling of myths and fairy tales (Oates, 2015). Or perhaps the ideas, and their advocates, are like itinerant workers moving from harvest to harvest or sales representatives selling patent medicines and universal panaceas, curing everything from toothache to diphtheria. But the notion of ideas traveling across borders relatively freely is appealing and does reflect the reality that some educational policies, like income contingent student loans (ICLs), did spread across borders over the last thirty to forty years. ICL schemes operate in countries as different as Ethiopia and England but the schemes vary significantly particularly around key design points like the effective interest rate on the loans, which can be zero or are tied to a central bank lending rate (Chapman \& Dearden, 2018). Sometimes the adoption is short lived as in the case of Thailand, where an ICL operated for one year (Chapman \& Lounkaew, 2010).

Of course, just as travelers can be robbed, kidnapped, and delayed in transit, traveling policies can be "hijacked by local policy makers and used for their own purposes locally" (Silova 2005). Those purposes can be legitimation of existing practice, apparent compliance to secure a loan, or gift or appropriation of the terms and symbols of a policy to imply a change of behavior without observable change occurring.

\section{Policy Borrowing}

Policy borrowing was another popular image, but there was seldom any reference to returning the borrowed item or paying off the loan. Still, it is a more polite expression than policy theft or intellectual plagiarism. But the public policy scholars talk about practitioners and policy advisers "pinching" ideas (Schneider \& Ingram, 1988) or "nicking stuff from all over the place" (Dwyer \& Ellison, 2009) and encourage them to be either more systematic (Schneider \& Ingram, 1988) or less linear (Dwyer \& Ellison, 2009). There is no moral approbation.

Both the pinching and nicking formulations can be applied to the acquisition of parts of policies or some aspect of a national or regional system of education. It does not apply only to the "whole cloth". Winstanley (2012) refers to "cherry picking," which can range from selecting a comparative nation to legitimize a practice to selecting a product or practice like the teaching of mathematics in Switzerland (p.525). The selections are usually purposeful, 
even when they are guided by ideology rather than evidence of effectiveness. A counter view was offered by Halpin and Troyna (1995) who, reflecting on education policy in England in the 1990's, found policy borrowing to be a short-term expedient act of legitimation where form mattered more than substance.

Policy copying is less pejorative but like borrowing or theft it carries a sense that the reform or idea was taken and adopted unchanged. Yet one of the central tenets of comparative education is that as an idea or practice moves across cultures or contexts it changes because the context changes. The policy is interpreted rather than simply transposed, adapts to local norms and values, is shaped by history and domestic priorities, and is transformed by the actors in the new environment. Or more simply, while the policy is borrowed, the enabling conditions that made it an enviable success are not automatically attached to it, and there is some conscious behavior by individuals or groups who advocate or implement the policy idea. Tanaka's (2009) study of the mobility of universities illustrates how the German ideal of the research universities was transferred to the USA by academics who, having experienced directly the benefits of "freedom of teaching and learning" (p.411), embedded it in graduate schools. In contrast, the transfer of the same idea to Japan was led by politicians "who were trying to build a modern state as soon as possible" and paid less attention to the fundamentals of academic freedom (p.408).

This is echoed by Gonzalez's (2011) study of urban renewal in Barcelona and Bilbao, which found that the contrasting approaches generated waves of policy tourism as different cities and regions looked for lessons that could be replicated or emulated or inform policy formation. Gonzalez concludes that policy diffusion is not "unidirectional” (p.1414). Nor do ideas about urban regeneration travel "international knowledge circuits" or networks in a fixed or invariant form; they adapt to circumstances (p.415).

\section{Silent and Dysfunctional Borrowing}

Policy borrowing is often a highly visible act, especially when there is a desire for legitimation, but not all policy borrowing is publicly acknowledged. Sometimes the borrowing is "silent," as in the case of Sweden in the period from 1960 to 1990. The influence of international practice and models was unacknowledged to maintain the public perception that Swedish education policy was primarily the product of rational processes that had produced an outstanding system. Legitimation of reforms and strategic choices by reference to practice elsewhere was not politically expedient (Waldow, 2009).

Nor is all policy transfer benign. Studying the spread of tax policies designed to limit access to tax havens Sharman (2010) found some transfers to be "dysfunctional." Policies, such as limiting financial transactions to "blacklisted" locations to counter tax evasion, were adopted by many nations in the mid 1990 to the mid 2000 period. Often this was pursued by simply copying the blacklist of jurisdictions from another nation, including the errors in the list such as miss-named and misspelt entities, non-existent entities, and places that had no banking facilities - even, in one instance, an island of eight families which had no monetary system (Sharman, 2010). This brief survey of policy mobility in fields as diverse as city planning, political science, rural and economic development, and public policy give us some insights that can inform policy movement in the field of education.

\section{What Can We Learn?}

The notion advanced by Phillips \& Ochs $(2003$; 2004) that educational policy borrowing goes through four stages of cross-national attraction, decision-making, implementation, and internalization or indigenization is a useful initial framework to explore 
processes of policy transfer. This conceptual tool focuses on the processes of transfer instead of outcomes, but it is an overly linear model which does not allow for multiple paths, the flow of information, or feedback loops or iterative exchanges that shape and reshape the policy idea as it moves.

The typology developed by Phillips and Ochs confines the possibility of variation to the final stage of internalization or indigenization. As can be seen in the wider policy mobility literature, variation occurs as ideas move, be it at the point of initial observation, in documentation, in interpretation, or in adaptation to a different political economy. Variation also occurs at the point of implementation and will continue over time. The images of adaptation and hybridization and the observation that the policy will change as it moves point to one of the shortcomings in much of the traveling policy literature: the assumption that policies move and are adopted and implemented without variation. Abrahamson (2006) observes that, in the diffusion of innovation literature, there are two common assumptions: 1) that policies are "invariant" as they move; and 2) that all borrowers adopt the new practice for the same reason. Both are questionable, maybe even flawed.

Traveling policies are usually seen as one-directional ideas and processes flowing from center to periphery from developed to developing economies and colonizer to colony. Some of the flows are the result of what Silova calls "forces of western hegemony ...colonialism, international development, best practices or even charitable donations and gifts" (Silova, 2018). But as these diffused or transferred policies "acquired new forms and different meaning (they)... become reinterpreted by local stakeholders under different conditions" (Silova 2018).

This is more than the basic proposition that ideas change as they move. The linear model of traveling policies has no notion of reciprocity or feedback paths which inform the originating institution. It is as if there is an impermeable membrane preventing information about the fate of the borrowed practices when they reach the site of adoption and implementation. Yet we know that ideas as well as goods flowed in both directions on the Silk Routes - an enduring example of policy mobility (Millward, 2013; Starr, 2013) - and that the medicinal value of plants gathered in new lands improved the lives of the colonizing and imperial nations' citizenry (Adelman, 2015).

The manner with which educational reforms are transferred across boundaries is thought to run from "imposed, required under constraint, negotiated under constraint, borrowed purposefully, and introduced through influence" (Ochs \& Phillips, 2004). The strength of this continuum is that it allows for deliberate action by the sovereign state that is "borrowing" the policy or reform. It provides for purposeful and selective adoption or adaptation of policy ideas. The state is not always a passive recipient of imperialist policy transfer.

The wider literature offers a more nuanced reading of imposition and constraint. Policy conditions on development bank loans and credits are examples of coerced policy diffusion. And the embrace of key elements of the Bologna Process by Francophone nations to increase access to employment opportunities can be economically rational and in the interests of the students. Sahlberg (2006) and many others cite national governments' desire for greater economic competitiveness as a motive for the pursuit of better human capital policies. And there are clearly instances where this has been a factor in the process of policy borrowing, like Australia's "Clever Country" strategies in the 1990's (Lowe, 1998) and Kazakhstan’s trilingual education policy (Mehisto \& Genesee, 2015). 


\section{Conclusion}

Ideas move across borders as readily as people do, but they are more liable to and more amenable to adaptation - particularly if people associated with institutions such as schools and universities purposefully decide to look for and adapt new ideas.

Our review of policy transfer literature from both education and other fields shows that a lot of the language about traveling policies conveys a sense of a linear process; a transfer that is logical, unidirectional, and conducted with an air of beneficence. It overlooks the sovereignty and the authority of the recipient and undervalues the national policy makers' deep understanding of the domestic context.

Research in other fields can help us better understand the processes of policy transfer and provide more examples that can highlight issues and pitfalls that are not yet captured in the field of education. As we show here, non-linear transfer and unplanned, unintended adaptation and adoption often takes place. There are possibilities that actors will purposefully or unconsciously vary the idea or policy as it is implemented in a new setting - a possibility that the field has been aware of for 30 years or more (see for example, McLaughlin, 1991).

The spread of policy ideas can proceed unevenly, yet it can be intentional both on the part of a transmitting state and the recipient state. An idea can follow the path of least resistance or be channeled. It can meet barriers and move around them or morph to accommodate them. Fidelity of implementation should not be assumed or even expected; indeed, we expect fidelity to diminish and variation in policy implementation to increase with time and distance. The speed of policy transfer can be variable, fast, slow, or intermittent - it might even ebb or recede. In practice, transfer processes include interaction and iterative exchanges between actors with experiences and successes and failures providing feedback as implementation occurs. These exchanges shape the idea or policy producing variants or refined forms of a policy. As a result, we argue that policy transfer is a more dynamic and more adaptable process than the bounded cyclical and linear models often used in education policy debates.

\section{References}

Abrahamson, E. (2006). Review of global ideas: How ideas, objects and practices travel in the global economy. Administrative Science Quarterly, 51(3), 512-514. https://doi.org/10.2189/asqu.51.3.512

Adelman, J. (2015). Mimesis and rivalry: European empires and global regimes. Journal of Global History, 10 (1), 77-99. https://doi.org/10.1017/S1740022814000291

Auld, E. \& Morris, P. (2014). Comparative education, the 'New Paradigm' and policy borrowing: Constructing knowledge for educational reform. Comparative Education, 50(2), 129-155. https://doi.org/10.1080/03050068.2013.826497

Bazbauers, A.R. (2017). The World Bank and transferring development: Policy movement through technical assistance. Palgrave Macmillan.

Beech, J. (2009). Policy spaces, mobile discourses, and the definition of education identities. Comparative Education, 45(3), 347-364.

https://doi.org/10.1080/03050060903184932

Brown, L.A. (1981). Innovation diffusion: A new perspective. Methuen.

Chapman, B. and Dearden, L. (2018, 11 April). The international transformation in student loan systems. University World News, No: 501. Retrieved from https://www.universityworldnews.com/post.php?story=20180411082843685 
Chapman, B., \& Lounkaew, K. (2010). Income contingent student loans for Thailand: Alternatives compared. Economics of Education Review, 29(5), 695-709.

https://doi.org/10.1016/j.econedurev.2010.04.002

Dwyer, P., \& Ellison, N. (2009). "We nicked stuff from all over the place": Policy transfer or muddling through? Policy $\mathbb{E}^{2}$ Politics, 37(3), 389-407. https://doi.org/10.1332/030557309X435862

Erlingsdottir, G., \& Lindberg, K. (2005). Isomorphism, isopraxism, and isonymism: Complementary or competing processes? In B. Czarniawska \& G. Sevon (Eds.), Global ideas: How ideas, objects and practices travel in the global economy (pp. 47-70). Liber \& Copenhagen Business School Press.

Eta, E.A., \& Vuban, J.A. (2018). Educational policy borrowing in the Cameroonian higher education system: A debatable paradigm from stakeholders. FIRE: Forum for International research in Education, 4(3), 77-94. https://doi.org/10.32865/fire2018436

Garrett, G., Dobbin, F., \& Simmons, B.A. (2008). Conclusion. In B.A. Simmons, F. Dobbin \& G. Garrett (Eds.), The global diffusion of markets and democracy (pp.344-360). Cambridge University Press.

Godin, B. (2014). Invention, diffusion and linear models of innovation: The contribution of anthropology to a conceptual framework. Journal of Innovation Economics and Management, 3(15), 11-37. https://doi.org/10.3917/jie.015.0011

Gonzalez, S. (2011). Bilbao and Barcelona 'in Motion'. How urban regeneration 'models' travel and mutate in the global flows of policy tourism'. Urban Studies, 48(7), 13971418. https://doi.org/10.1177/0042098010374510

Graham, E., Shipan, C., \& Volden, C. (2012). The diffusion of policy diffusion research in political science. British Journal of Political Science, 43(3), 673-701. https://doi.org/10.1017/So007123412000415

Halpin, D., \& Troyna, B. (1995). The politics of education policy borrowing. Comparative Education, 31(3), 303-310.

Jules, T.D., \& Bouhlila, D.S. (2018). Indirect coercive transfer and educational copying under dictatorship: the case of Tunisia. FIRE: Forum for International Research in Education, 4(3), 95-113. https://doi.org/10.32865/fire20184316

Lowe, I. (1998). The Clever Country? Retrieved from https://www.abc.net.au/science/slab/clever/story.htm

McLaughlin, M.W. (1991). The rand change agent study: Ten years later. In Odden, A.R. (Ed.), Education policy implementation (pp.143-156). SUNY Press.

Massey. A. (2009). Policy mimesis in the context of global governance. Policy Studies, 30(3), 383-395. https://doi.org/10.1080/01442870902888940

Mehisto. P, \& Genesee. F. (Eds.). (2015). Bilingual education systems. University Press, Cambridge.

Millward, J.A. (2013). The Silk Road: A very short introduction. Oxford University Press.

Nir,A., Kondakci, Y., \& Emil, S. (2017). Travelling policies and contextual considerations: On threshold criteria. Compare: A Journal of Comparative and International Education, 48(1), 21-38. https://doi.org/10.1080/03057925.2017.1281102

Oates, T. (2010). Could do better: Using international comparisons to refine the national curriculum in England. Cambridge Assessments. Retrieved from https://www.cambridgeassessment.org.uk/Images/112281-could-do-better-usinginternational-comparisons-to-refine-the-national-curriculum-in-england.pdf 
Oates, T. (2015). Finnish Fairy Stories. Cambridge Assessments. Retrieved from https://www.cambridgeassessment.org.uk/Images/207376-finnish-fairy-storiestim-oates.pdf

Ochs, K., \& Phillips, D. (2004). Processes of educational borrowing in historical context. Oxford Studies in Comparative Education, 14(1), 7-23.

Peck, J. \& Theodore, N. (2010). Mobilizing policy: Models, methods, and mutations. Geoforum, 41 (2), 169-174. https://doi.org/10.1016/j.geoforum.2010.01.002

Phillips, D., \& Ochs, K. (2003). Processes of policy borrowing in education: Some explanatory and analytical devices. Comparative Education, 39(4), 451-461.

Phillips, D., \& Ochs, K. (Eds.). (2004). Educational policy borrowing: Historical perspectives. Symposium Books.

Portnoi, L.M. (2016). Policy borrowing and reform in education: Globalized processes and local contexts. Palgrave Macmillan.

Rappleye, J. (2011). Reimagining attraction and "borrowing" in education. In G. SteinerKhamsi \& F. Waldow (Eds.), World yearbook of education 2012: Policy borrowing and lending in education (pp. 121-147). Routledge.

Robertson, D.B., \& Waltman, J.L. (1993). The politics of policy borrowing. In D. Finegold, L. McFarland, \& W. Richardson (Eds.), Something borrowed, something learned: The transatlantic market in education and training reform. The Brookings Institution.

Rogers, E.M. (2003). Diffusion of innovation (5 ${ }^{\text {th }}$ Edition). New York: Free Press.

Rose, R. (2004). Learning from comparative public policy: A practical guide. Routledge.

Sahlberg, P. (2006). Education reform for raising economic competitiveness. Journal of Educational Change, 7, 259-287. https://doi.org/10.1007/s 10833-005-4884-6

Sahlberg, P. (2015). Finnish lessons 2.0: What can the world learn from educational change in Finland? Teachers College Press.

Sautoy, P. (1967). How ideas travel. Community Development Journal, 2(5), 42-46. https://doi.org/10.1093/cdj/2.5.42

Schneider, A., \& Ingram, H. (1988). Systematically pinching ideas: A comparative approach to policy design. Journal of Public Policy, 8(1), 61-80. https://doi.org/10.1017/So 143814X00006851

Sharman, J. (2010). Dysfunctional policy transfer in national tax blacklists. Governance, 23(4), 623-639. https://doi.org/10.1111/j.1468-0491.2010.01501

Silova, I. (2005). Traveling policies: Hijacked in Central Asia. European Educational Research Journal, 4(1), 50-59. https://doi.org/10.2304/eerj.2005.4.1.5

Silova, I. (2010). Rediscovering post-socialism in Comparative Education. In I. Silova (Ed.), Post-socialism is not dead: (Re) reading the global in Comparative Education (pp. 1-24). International Perspectives on Education and Society 14(1). Emerald.

Silova, I. (2018). Comparing post-socialist transformations: Dead ends, new pathways and unexpected openings. In M. Chankseliani \& I. Silova (Eds.) Comparing post-socialist transformations: Purposes policies, and practices in education (pp. 193-200). Oxford Studies in Comparative Education, 28(2). Symposium Books.

Sprigade, A. (2004). Educational comparison in England during the first half of the nineteenth century. In D. Phillips \& K. Ochs (Eds.), Educational policy borrowing: Historical perspectives (pp. 37-58). Symposium Books.

Starr, S. F. (2013). Lost enlightenment: Central Asia's golden age from the Arab conquest to Tamerlane. Princeton University Press. 
Steiner-Khamsi, G. (2014). Cross-national policy borrowing: Understanding reception and translation. Asia Pacific Journal of Education Review, 34(2), 153-167.

https://doi.org/10.1080/02188791.2013.875649

Stone, D. (2012). Transfer and translation of policy. Policy Studies, 33(6), 483-499. https://doi.org/10.1080/01442872.2012.695933

Strang, D., \& Soule, S.A. (1998). Diffusion in organizations and social movements: From hybrid corn to poison pills. American Review of Sociology, 24, 265-299.

https://doi.org/10.1146/annurev.soc.24.1.265

Sung, Y-K. (2011). Cultivating borrowed futures: The politics of neoliberal loanwords in South Korean cross-national policy borrowing. Comparative Education, 47(4), 523538. https://doi.org/10.1080/03050068.2011.555118

Tanaka, M. (2009). The mobility of universities. Comparative Education, 45(3), 405- 418. https://doi.org/10.1080/03050060903184965

Varia, M. (2004). Globalization and higher education organizational change: A framework for analysis. Higher Education, 48(4), 483-510.

https://doi.org/10.1023/B:HIGH.0000046711.31908.e5

Waldow, F. (2009). Undeclared imports: silent borrowing in educational policy-making and research in Sweden. Comparative Education, 45(4), 477-494. https://doi.org/10.1080/03050060903391628

Winstanley, C. (2012). Alluring ideas: Cherry picking policy from around the world. Journal of Philosophy of Education, 46(4), 516-531. https://doi.org/10.1111/j.14679752.2012.00876.x

\section{About the Authors}

Alan Ruby has a long career in government, business, philanthropy, and education, ranging from classroom teacher to Australian deputy secretary of education and to chair of the OECD education committee. At the University of Pennsylvania, Mr. Ruby, a Senior Fellow in the Alliance for Higher Education and Democracy, focuses on globalization's effects on universities and education around the world. A highly regarded teacher, he leads graduate seminars on "Globalization and the University." He earned the School's Excellence in Teaching Award in 2006. Since early 2018, he also served as the initial director of the Global Engagement office at GSE, advising the Dean on ways to increase the school's international impact.

Mr. Ruby currently serves as a Trustee of Nazarbayev University and the Nazarbayev Intellectual Schools in Kazakhstan. His involvement with Kazakhstan's education reform and development began in 2009 and continues with his membership on the Technical Advisory Panel for a World Bank-funded project aimed at strengthening the rural schools of the nation. He has served as a consultant to the Government of India, the World Bank, the HEAD Foundation in Singapore, higher education officials in Bhutan and Indonesia, and the American Institutes of Research. In 2015, he was made a Member of the Order of Australia (AM) for significant service to international education through global reform initiatives and his work with philanthropic organizations. He reviews for the Journal of Studies in International Education (2016) and Online Learning journal (2015- 2017)."

Aisi $\mathrm{Li}$ is an Assistant Professor of Nazarbayev University Graduate School of Education. She specializes in internationalization of higher education both from a historical and contemporary perspective. Her recent projects take a special interest in the internationalization of higher education in Kazakhstan, as well as the impacts of China's Belt and Road Initiative on higher education in Central Asia. 